\title{
CALENDAR ANOMALIES AND CAPITAL MARKET EFFICIENCY: LISTED PROPERTY TRUST INVESTMENT STRATEGIES
}

\author{
VINCENT PENG \\ University of Western Sydney
}

\begin{abstract}
This study focuses on the efficient market hypothesis (EMH) and inspects the existence of calendar anomalies in the Australian capital markets. It is the first study that provides a comprehensive examination of calendar anomalies in the Australian capital markets, particularly in the Australian Listed Property Trust (LPT) market. The study reveals that calendar anomalies exist in both the Australian LPT market and the broader equity market, providing evidence of market inefficiency. It is also found that some of these return irregularities are diminishing and dissipating over time, suggesting the move towards a higher level of efficiency.

The results from this study provide support to active investing. Moreover, this study quantifies the potential for profiting on the calendar anomalies by active investing in a practical sense and provides significant practical implications for LPT portfolio managers and investors.
\end{abstract}

Keywords: LPTs, EMH, calendar anomalies, investment strategy.

\section{INTRODUCTION}

The efficient market hypothesis (EMH) has significant implications for capital market investment strategies. If capital markets are perfectly efficient, investment strategies should simply concentrate on the construction of a portfolio that accommodates the risk-return preferences of the investors, because no abnormal returns can be realised if all securities are already fully priced and any attempts to outperform the market would simply be of limited value. In such a case, any outperformance by active management is purely luck rather than skill. If the EMH does not hold, there exist opportunities for portfolio managers to exploit abnormal returns in the market, supporting active investing.

The EMH suggests that all securities prices reflect all relevant information. Based on the infusion of such information, market efficiency takes three forms: the weak form, the semi-strong form and the strong form (Fama, 1970). Details on the three forms of market efficiency and their practical implications are demonstrated by Peng (2004a). 
Table 1: Three forms of market efficiency

\begin{tabular}{lll}
\hline \multicolumn{1}{c|}{ Efficiency Form } & \multicolumn{1}{c}{ Level of Information Infusion } & \multicolumn{1}{c}{ Practical Implication } \\
\hline Weak Form & $\begin{array}{l}\text { Current prices fully reflect all past information } \\
\text { concerning the securities. Future price changes are } \\
\text { random. }\end{array}$ & $\begin{array}{l}\text { Relating to 'Price Predictability' and "technical Analysis' -- If this } \\
\text { level of efficiency holds, securities prices should follow a random } \\
\text { walk, and prices in the future cannot be predicted by studying } \\
\text { historical prices, questioning the relevance of Technical Analysis. }\end{array}$ \\
Semi-strong Form & Securities prices reflect all public information. & $\begin{array}{l}\text { Relating to 'Events' and 'Calendar Anomalies' -- If this level of } \\
\text { efficiency holds, prices should only changes with the infusion of } \\
\text { new market information such as announcements, and there should } \\
\text { not exist patterns of anomalous regularities, such as calendar } \\
\text { anomalies. }\end{array}$ \\
Strong Form & $\begin{array}{l}\text { Securities prices reflect all information including } \\
\text { private information }\end{array}$ & $\begin{array}{l}\text { Relating to 'Insider Trading' - If this level of efficiency holds, } \\
\text { there should not exist abnormal returns from insider trading. }\end{array}$ \\
\hline
\end{tabular}

Peng (2004a) examines EMH for the Australian capital markets by investigating daily closing prices of Listed Property Trusts (LPTs) and All Ordinaries. Based on the results of unit root tests and co-integrating analysis, Peng (2004a) provides evidence that the Australian capital markets are efficient in the weak form.

This study focuses on the semi-strong form EMH and investigates whether calendar anomalies exist in the Australian LPT market, by means of a comprehensive examination of the daily closing prices of LPTs for the period of 1 June 1992 to 31 May 2003. For comparison purposes, this study also tests the EMH for the broader Australian equity market.

Numerous studies have investigated the existence of calendar anomalies for common stocks and evidence of several calendar anomalies has been well documented by the finance literature. Evidence of the day-of-the-week effect, where returns for stocks are normally lower on Monday than the other days, has been documented; for example, Wang, Li and Erickon (1997); Abraham and Ikenberry (1994); Admati and Pfleiderer (1989); Flannery and Protopapadakis (1988); Harris (1986); Jaffe and Westerfield (1985); Keim and Stambaugh (1984); Gibbons and Hess (1981); French (1980); Cross (1973).

Evidence of the monthly effect, where returns are higher in a certain month or months than the other months, has been documented by Roll (1983), Keim (1983, 1985), and Rozeff and Kinney (1976). Since January is normally the month with higher returns, the month effect is also commonly known as the January effect. Brown, Keim, Kleidon and Marsh (1983) find that average returns to most Australian stocks are substantially higher, not only in January, but also in July, compared with the other ten months. 
Ariel (1987) and Ogden (1990) have provided evidence of the turn-of-the-month anomaly, which implies that returns are greater on the turn-of-the-month trading days than otherwise. Ariel (1990) has also documented the pre-holiday effect, with returns being higher on trading days before holidays than the other days of the year.

In general, studies on common stocks have shown that abnormal returns can be earned at different times of a week, a month or year, contrary to the implications of the EMH.

In the real estate markets, a few studies have investigated the existence of calendar anomalies in the US REIT market. Friday and Higgins (2000) provided evidence of the day-of-the-week effect. Colwell and Park (1990) and Liu and Mei (1992) noticed evidence of the January effect. Redman, Manakyan and Liano (1997) conducted an extensive examination of calendar anomalies for US REITs and provided evidence that there exist the January effect, the turn-of-the-month effect, the day-of-the-week effect and the pre-holiday effect in the REITs market. However, in the literature search, no previous studies have been found investigating the calendar anomalies in the Australian securitised property market.

This study provides a comprehensive examination of calendar anomalies in the Australian capital market, particularly in the LPT market. In the field of real estate studies, it puts the examination of calendar anomalies into the context of EMH inspection.

The remainder of this paper is structured as follows. Section two briefly describes the data and then introduces and justifies the methodology used in this study. Section three provides results and analysis of the examination of calendar anomalies. Practical implications are illustrated and discussed in section four, and the last section provides concluding comments.

\section{DATA AND METHODOLOGY}

\section{Data}

Data used in this study are the market daily closing price indices for the LPT 300 and All Ordinaries over the period of 1 June 1992 to 31 May 2003, sourced from the Australian Stock Exchange (ASX).

There are totally 2786 trading days over this period. Simple daily (as opposed to logarithmic returns) are calculated for each of the 2786 days and used in this study, to conform to the common practices in the marketplace (Peng, 2004b).

Table 2 provides some descriptive analysis of the data used for this study. 
Table 2: Summary of descriptive statistics (1 June 1992 - 30 May 2003)

\begin{tabular}{|c|c|c|c|c|c|}
\hline \multicolumn{6}{|c|}{ Daily Returns (Day-of-the-Week Effect) } \\
\hline \multirow[b]{2}{*}{$D A Y$} & \multirow[b]{2}{*}{ Observations } & \multicolumn{2}{|c|}{$\underline{\text { LPTs }}$} & \multicolumn{2}{|c|}{$\underline{\text { All Ords }}$} \\
\hline & & Mean & Standard Deviation & Mean & Standard Deviation \\
\hline Monday & 535 & -0.00027 & 0.00615 & -0.00004 & 0.00932 \\
\hline Tuesday & 564 & 0.00074 & 0.00648 & 0.00015 & 0.00805 \\
\hline Wednesday & 567 & 0.00027 & 0.00640 & 0.00048 & 0.00858 \\
\hline Thursday & 567 & 0.00014 & 0.00606 & 0.00045 & 0.00744 \\
\hline Friday & 553 & -0.00001 & 0.00603 & 0.00008 & 0.00802 \\
\hline All & 2786 & 0.00018 & 0.00623 & 0.00023 & 0.00829 \\
\hline \multicolumn{6}{|c|}{ Daily Returns (Monthly Effect) } \\
\hline & & \multicolumn{2}{|c|}{$\underline{\text { LPTs }}$} & \multicolumn{2}{|c|}{ All Ords } \\
\hline Month & Observations & Mean & Standard Deviation & Mean & Standard Deviation \\
\hline January & 222 & 0.00003 & 0.00650 & 0.00050 & 0.00828 \\
\hline February & 222 & -0.00012 & 0.00637 & 0.00002 & 0.00754 \\
\hline March & 240 & 0.00001 & 0.00620 & -0.00018 & 0.00835 \\
\hline April & 209 & 0.00026 & 0.00571 & 0.00140 & 0.00870 \\
\hline May & 244 & 0.00029 & 0.00493 & -0.00007 & 0.00705 \\
\hline June & 225 & 0.00019 & 0.00584 & 0.00012 & 0.00719 \\
\hline July & 244 & 0.00109 & 0.00626 & 0.00015 & 0.00792 \\
\hline August & 243 & -0.00057 & 0.00623 & -0.00028 & 0.00775 \\
\hline September & 236 & 0.00022 & 0.00691 & -0.00062 & 0.00946 \\
\hline October & 243 & -0.00019 & 0.00767 & 0.00015 & 0.01029 \\
\hline November & 236 & 0.00040 & 0.00570 & 0.00039 & 0.00810 \\
\hline December & 222 & 0.00055 & 0.00599 & 0.00142 & 0.00822 \\
\hline All & 2786 & 0.00018 & 0.00623 & 0.00023 & 0.00829 \\
\hline \multicolumn{6}{|c|}{ Daily Returns (Pre-Holiday Effect) } \\
\hline & & \multicolumn{2}{|c|}{$\underline{\text { LPTs }}$} & \multicolumn{2}{|c|}{ All Ords } \\
\hline Pre-Holiday & Observations & Mean & $\overline{\text { Standard Deviation }}$ & Mean & $\overline{\text { Standard Deviation }}$ \\
\hline No & 2725 & 0.00015 & 0.00625 & 0.00022 & 0.00834 \\
\hline Yes & 61 & 0.00138 & 0.00510 & 0.00056 & 0.00611 \\
\hline All & 2786 & 0.00018 & 0.00623 & 0.00023 & 0.00829 \\
\hline \multicolumn{6}{|c|}{ Daily Returns (Turn-of-the-Month Effect) } \\
\hline & & \multicolumn{2}{|c|}{$\underline{\text { LPTs }}$} & \multicolumn{2}{|c|}{ All Ords } \\
\hline Turn-of-the-Month & Observations & Mean & Standard Deviation & Mean & Standard Deviation \\
\hline No & 2277 & 0.00007 & 0.00612 & 0.00005 & 0.00828 \\
\hline Yes & 509 & 0.00066 & 0.00669 & 0.00102 & 0.00830 \\
\hline All & 2786 & 0.00018 & 0.00623 & 0.00023 & 0.00829 \\
\hline
\end{tabular}

\section{Methodology}

This study investigates the existence of calendar anomalies in the Australian LPT market and the broader equity market, including a comprehensive examination of the day-of-the-week effect, the monthly effect, the turn-of-the-month effect and the pre-holiday effect. The existence of those calendar anomalies would suggest that 
the infusion of new information is not the only factor that changes securities prices, violating the semi-strong form EMH. The methods are detailed as follows.

Day-of-the-week effect

Equation (1) is the regression used to examine the day-of-the-week effect, with dummy variables representing the days of the week.

$$
R_{t}=a_{1}+a_{2} D_{2, t}+a_{3} D_{3, t}+a_{4} D_{4, t}+a_{5} D_{5, t}+\varepsilon_{t}
$$

where:

$R_{t}$ is the daily return on day $t$

$\mathrm{D}_{2, t} \ldots \mathrm{D}_{5, t}$ is 1 if day $t$ is Tuesday...Friday, and 0 otherwise

$\varepsilon_{t}$ is the error term.

In equation (1), the intercept measures the average daily return on Monday. A positive and significant intercept implies that the average return on Monday is significantly greater than zero. The coefficients $a_{2}$ through $a_{5}$ are the pairwise comparison between the average return on Monday and the average return on Tuesday through Friday. A positive and significant $a_{2}$ indicates that the average return on Tuesday is significantly higher than that on Monday. The coefficients for the remaining three dummy variables are interpreted similarly.

The $F$-value from equation (1) measures the joint significance of the coefficients. In addition to the parametric test, a nonparametric van der Waerden test (Conover, 1980 ) is conducted to test the equality of returns across the days of the week. A significant $F$-value and van der Waerden test would reject the hypothesis that returns are equal across days, providing evidence of the day-of-the-week effect.

In addition to testing for the joint hypothesis, this paper also tests whether the average daily return on Monday or Tuesday is significantly different from the rest of the week as a whole, using the following equation:

$$
R_{t}=a_{1}+a_{2} D_{2, t}+\varepsilon_{t}
$$

where:

$D_{2, t}$ is 1 if day $t$ is Monday, and 0 otherwise in the test for Monday; is 1 if day $t$ is Tuesday, and 0 otherwise in the test for Tuesday; and all other variables are as defined immediately above.

In equation (2), the intercept measures the average daily rate of non-Mondays (or non-Tuesdays) as a whole, and the coefficient $a_{i}$ is the pairwise comparison between the average return on Monday and that for the rest of the week as a whole. 
Equation (3) is the regression used to examine the day-of-the-week effect, with dummy variables representing the months of the year.

$$
R_{t}=a_{1}+a_{2} D_{2, t}+a_{3} D_{3, t}+a_{4} D_{4, t}+\ldots+a_{11} D_{11, t}+a_{12} D_{12, t}+\varepsilon_{t}
$$

where:

$\mathrm{D}_{2, t} \ldots \mathrm{D}_{12, t} \quad$ is 1 if day $t$ falls in the months of February...December, and 0 otherwise; and all other variables are as defined immediately above.

In equation (3), the intercept measures the average daily return in January. The coefficients $a_{2}$ through $a_{12}$ are the pairwise comparison between the average return in January and the average return in February through December.

In addition to testing for the joint hypothesis, this paper also tests whether the average daily return in July is significantly different from the rest of the year as a whole, using the following equation:

$$
R_{t}=a_{1}+a_{2} D_{2, t}+\varepsilon_{t}
$$

where:

$D_{2, t}$ is 1 if day $t$ falls in July, and 0 otherwise; and all other variables are as defined immediately above.

In equation (4), the intercept measures the average daily return in the months other than July as a whole, and the coefficient $a_{2}$ is the pairwise comparison between the average return in July and that for the rest of the year as a whole.

All coefficients and test statistics are analysed and interpreted in a similar way to that for the day-of-the-week effect.

\section{Pre-holiday effect}

This study compares the returns on trading days before eight Australia national holidays (New Year's Day, Australia Day, Good Friday, Easter Monday, Anzac Day, Queen's Birthday, Christmas Day and Boxing Day) to the returns on non-preholiday trading days.

Equation (5) is used to examine whether the pre-holiday returns to LPTs and All Ordinaries are significantly different from the non-pre-holiday returns.

$$
R_{t}=a_{1}+a_{2} D_{2, t}+\varepsilon_{t}
$$


where:

$D_{2, t}$ is 1 if day $t$ is a pre-holiday trading day, and 0 otherwise; and all other variables are as defined immediately above.

A significant intercept suggests that the returns on non-pre-holiday trading days are significantly different from zero. A positive and significant coefficient implies that pre-holiday returns are significantly higher than non-pre-holiday returns, providing evidence of the pre-holiday effect. A significant $F$-value and van der Waerden test also supports the existence of a pre-holiday effect.

Turn-of-the-month effect

To analyse the turn-of-the-month effect, trading days are classified into turn-of-themonth trading days (the final trading day of the previous month and the first three trading days of the current month) and non-turn-of-the-month trading days, a definition adopted from Ogden (1990) and Redman, Manakyan and Liano (1997).

Equation (6) is used to compare turn-of-the-month and non-turn-of-the-month returns.

$$
R_{t}=a_{1}+a_{2} D_{2, t}+\varepsilon_{t}
$$

where:

$D_{2, t}$ is 1 if day $t$ is at the turn-of-the-month, and 0 otherwise; and all other variables are as defined immediately above.

In equation (6), the intercept measures the average daily rate of return on non-turnof-the-month trading days. A positive and significant coefficient indicate that turnof-the-month trading rates of return are significantly higher than non-turn-of-themonth trading returns, providing evidence of the turn-of-the-month effect. A significant $F$-value and van der Waerden test also indicates the presence of a turnof-the-month effect.

The ordinary least square regressions of equations (1) to (6) assume equal variances and no serial correlation. The Durbin-Watson (DW) statistic is used to check for the presence of serial correlation. The Levene test (Brown and Forsythe, 1974) is used to check for the equality of variances. A significant Levene test suggests the presence of heteroscedasticity.

In the absence of serial correlation and heteroscedasticity, the t-statistics are the standard OLS t-statistics. In the presence of heteroscedasticity, the White (1980) adjusted t-statistics are reported. In the presence of serial correlation or both serial correlation and heteroscedasticity, the t-statistics will be corrected using the technique of Hansen (1982).

Pacific Rim Property Research Journal, Vol 11, No 1 


\section{RESULTS AND ANALYSIS}

Day-of-the-week effect ${ }^{l}$

A significant van der Waerden statistic and F-value would reject the joint hypothesis that returns are equal across days, providing evidence of the day-of-theweek effect. In Table 3, van der Waerden statistic and F-value are significant for LPTs but not for All Ordinaries, suggesting that daily returns are not equal across days in LPTs market, but this inequality is not evidenced in the broader stock market.

Table 3: Day-of-the-week effect for LPT and stock markets (1 June 1992 - 30 May 2003)

\begin{tabular}{|c|c|c|c|c|}
\hline \multirow[b]{3}{*}{ Constant } & \multicolumn{2}{|c|}{ LPTs } & \multicolumn{2}{|c|}{ All Ords } \\
\hline & Coefficient & $t$-Statistics & Coefficient & t-Statistics \\
\hline & -0.00027 & -1.00735 & -0.00004 & {$[-0.09454]$} \\
\hline Tuesday & 0.00101 & $2.67970 * * *$ & 0.00019 & {$[0.35786]$} \\
\hline Wednesday & 0.00054 & 1.43691 & 0.00052 & {$[0.96076]$} \\
\hline Thursday & 0.00041 & 1.10277 & 0.00049 & {$[0.95960]$} \\
\hline Friday & 0.00026 & 0.69838 & 0.00012 & {$[0.23221]$} \\
\hline$D W$ & 1.98149 & & 1.92358 & \\
\hline Levene & 0.01327 & & $4.22105 * * *$ & \\
\hline van der Waerden & $8.12513 *$ & & 1.04630 & \\
\hline F-Value & $1.98446 *$ & & 0.42606 & \\
\hline
\end{tabular}

*** Significant at $1 \%$ level;

** Significant at $5 \%$ level;

* Significant at $10 \%$ level;

t-statistics in brackets are the White [1980] adjusted t-statistics.

The constant is the average daily return earned on Monday. The coefficients for Tuesday, Wednesday, Thursday and Friday are the excess daily returns (against that on Monday) earned on these days respectively. The average daily return on Monday for both LPTs and All Ordinaries are negative. However, this negative return is not statistically significant. The positive coefficients for Tuesday, Wednesday, Thursday and Friday indicate that average daily returns on these days are higher than that on Monday. However, the positive excess returns earned on these days are not significant, except for the excess return on Tuesday in the LPT market.

The coefficient for Tuesday is strongly significant (at $1 \%$ level) with a magnitude of 10.1 basis points, which implies that in the LPT market, the average daily return earned on Tuesday is about 10 basis points higher than that earned on Monday.

${ }^{1}$ In Table 2 through Table 10, the values of t-statistics in brackets are the White [1980] adjusted tstatistics. 
Over the 11-year study period, there are 531 pairs of trading Monday and Tuesday (i.e., a trading Monday followed by a trading Tuesday), translating into an average of $4.9 \%$ excess return per annum on Tuesday against the average return on Monday, if there were no transaction costs.

In Table 3, it appears that when compared with Monday individually, the higher return on each of the non-Mondays is insignificant except for Tuesday in the LPT market. It would be interesting to test whether the average daily return on nonMondays, collectively, is significantly higher than that on Monday. In other words, whether Monday has a significantly lower return than the rest of the week as a whole. Similarly, it would be interesting to test whether return on Tuesday is significantly higher than that on the rest of the week as a whole.

Table 4 shows the results of returns on Monday compared with the rest of the week as a whole.

Table 4: Monday effect for LPT and stock markets (1 June 1992 - 30 May 2003)

\begin{tabular}{|c|c|c|c|c|}
\hline \multirow[b]{3}{*}{ Constant } & \multicolumn{2}{|c|}{ LPTs } & \multicolumn{2}{|c|}{ All Ords } \\
\hline & Coefficient & $t$-Statistics & Coefficient & $t$-Statistics \\
\hline & 0.00029 & 2.17859 & 0.00029 & {$[1.73317] *$} \\
\hline Monday & -0.00056 & $-1.85992 *$ & -0.00033 & {$[-0.75846]$} \\
\hline$D W$ & 1.98118 & & 1.92348 & \\
\hline Levene & 0.02518 & & 9.41279 & \\
\hline van der Waerden & $3.23690 *$ & & 0.23018 & \\
\hline F-Value & $3.45931 *$ & & 0.69047 & \\
\hline
\end{tabular}

$* * *$ Significant at $1 \%$ level;

** Significant at $5 \%$ level;

* Significant at $10 \%$ level;

t-statistics in brackets are the White [1980] adjusted t-statistics.

Again, the van der Waerden statistic and F-value are significant for LPTs but not for All Ordinaries, suggesting that the returns are not equal between Monday and non-Mondays in the LPT market, but this inequality is not evidenced in the broader equity market. Also, in the LPT market, the average daily return on Monday is significantly lower than that on non-Mondays for about 5.6 basis points. With 535 trading Mondays over the 11-year study period (Table 2), buying on Mondays in the LPT market would have the potential to realise an excess return of $2.7 \%$ per annum over the study period if there were no transaction costs.

Table 5 compares the average daily returns on Tuesday and non-Tuesdays.

Pacific Rim Property Research Journal, Vol 11, No 1 
Table 5: Tuesday effect for LPT and stock markets (1 June 1992 - 30 May 2003)

\begin{tabular}{|c|c|c|c|c|}
\hline & \multicolumn{2}{|c|}{ LPTs } & \multicolumn{2}{|c|}{ All Ords } \\
\hline & Coefficient & $t$-Statistics & Coefficient & $t$-Statistics \\
\hline Constant & 0.00004 & 0.28520 & 0.00025 & [1.40942] \\
\hline Tuesday & 0.00070 & $2.37829 * *$ & -0.00010 & {$[-0.25994]$} \\
\hline$D W$ & 1.98121 & & 1.92300 & \\
\hline Levene & 0.01091 & & $4.80904 * *$ & \\
\hline van der Waerden & $6.33307 *$ & & 0.07365 & \\
\hline F-Value & $5.65624 * *$ & & 0.06463 & \\
\hline
\end{tabular}

$* * *$ Significant at $1 \%$ level;

** Significant at $5 \%$ level;

* Significant at $10 \%$ level;

t-statistics in brackets are the White [1980] adjusted t-statistics.

Again, the van der Waerden statistic and F-value are significant for LPTs, but not for All Ordinaries, suggesting that the returns are not equal between Tuesday and non-Tuesdays in the LPT market, but this inequality is not evidenced in the broader equity market. Also, in the LPT market, the average daily return on Tuesday is significantly higher than that on non-Tuesdays for about 7.0 basis points. With 564 trading Tuesdays over the 11-year study period (Table 2), selling on Tuesday could potentially earn an excess return of $3.6 \%$ per annum if there were no transaction costs.

In summary, there is evidence that the day-of-the-week effect exists in the LPT market, but not the broader stock market. In the LPT market, the average daily return on Monday is significantly lower than that on non-Mondays collectively, providing potential for abnormal returns by buying on Mondays. Also in the LPT market, the average daily return on Tuesday is significantly higher than that on nonTuesdays collectively, providing potential for abnormal returns by selling on Tuesdays.

\section{Monthly effect}

Table 6 shows the results of the tests for the January effect for LPTs and All Ordinaries.

In Table 6, the van der Waerden statistic and F-value are insignificant for both LPTs and All Ordinaries, suggesting that the null hypothesis can not be rejected and there is no evidence that the daily returns are not equal across months in LPTs and the broader stock markets. The insignificant constant (although positive) and the positive coefficients (although not all significant) for some months also suggest the non-existence of a January effect in LPTs and the broader equity market in Australia. 
Table 6:January effect for LPT and stock markets (1 June 1992 - 30 May 2003)

\begin{tabular}{|c|c|c|c|c|c|}
\hline \multicolumn{3}{|c|}{ LPTs } & \multicolumn{3}{|c|}{ All Ords } \\
\hline & Coefficient & t-Statistics & & Coefficient & t-Statistics \\
\hline Constant & 0.00003 & {$[0.07194]$} & Constant & 0.00050 & {$[0.90090]$} \\
\hline February & -0.00015 & {$[-0.25195]$} & February & -0.00048 & {$[-0.64187]$} \\
\hline March & -0.00002 & {$[-0.04059]$} & March & -0.00068 & {$[-0.87499]$} \\
\hline April & 0.00023 & {$[0.39609]$} & April & 0.00090 & {$[1.09347]$} \\
\hline May & 0.00026 & {$[0.48771]$} & May & -0.00058 & {$[-0.80324]$} \\
\hline June & 0.00016 & {$[0.26502]$} & June & -0.00038 & {$[-0.51612]$} \\
\hline July & 0.00106 & {$[1.78704] *$} & July & -0.00035 & {$[-0.46561]$} \\
\hline August & -0.00060 & {$[-1.00878]$} & August & -0.00078 & {$[-1.04079]$} \\
\hline September & 0.00019 & {$[0.30103]$} & September & -0.00112 & {$[-1.35167]$} \\
\hline October & -0.00022 & {$[-0.34016]$} & October & -0.00036 & {$[-0.41247]$} \\
\hline November & 0.00037 & {$[0.63664]$} & November & -0.00011 & {$[-0.14022]$} \\
\hline December & 0.00052 & {$[0.86784]$} & December & 0.00092 & {$[1.17290]$} \\
\hline$D W$ & 1.99061 & & $D W$ & 1.93058 & \\
\hline Levene & $0.02100 * *$ & & Levene & $2.21276 * *$ & \\
\hline van der Waerden & 12.88802 & & van der Waerden & 15.52733 & \\
\hline F-Value & 1.05037 & & F-Value & 1.23283 & \\
\hline
\end{tabular}

*** Significant at $1 \%$ level;

** Significant at $5 \%$ level;

* Significant at $10 \%$ level;

t-statistics in brackets are the White [1980] adjusted t-statistics.

In the LPT market, it appears that the average daily return in July is significantly higher than in January, suggested by the significantly positive coefficient. Thus, it would be interesting to examine whether returns in July are significantly different form those in other months in the LPT market.

Two hypothesis tests are performed. The first one is a joint test similar to that for January effect, but the constant would represent for July rather than January. The focus of this test would be on the coefficients and relevant $t$-statistics, because the Durbin-Watson, Levene and van der Waerden statistics, and the F-value would be expected to remain the same as those in the LPTs column in Table 6. That is, we focus on the comparison of returns between July and each of the other months. The second test is to compare the average daily return to July with that to all the other months as a whole; a test similar to those used in the section assessing the day-ofthe-week effect.

Table 7 presents the results of these two tests. The joint test suggests that the average daily return in July is positive and in the amount of 10.9 basis points, a figure consistent with that in Table 1 . This positive return is significant at the $1 \%$ level. All coefficients are negative, indicating that the average daily returns in each 
of the other months are lower than that in July. Of these negative coefficients, January, February, March, August and October are significant.

Table 7: July effect for LPT market (1 June 1992 - 30 May 2003)

\begin{tabular}{|c|c|c|c|c|c|}
\hline \multicolumn{3}{|c|}{ Joint Hypothesis } & \multicolumn{3}{|c|}{ July } \\
\hline & Coefficient & $t$-Statistics & & Coefficient & $t$-Statistics \\
\hline Constant & 0.00109 & {$[2.71935] * * *$} & Constant & 0.00009 & 0.74185 \\
\hline January & -0.00106 & {$[-1.78704] *$} & July & 0.00100 & $2.39151 * *$ \\
\hline February & -0.00121 & {$[-2.06950] * *$} & & & \\
\hline March & -0.00108 & {$[-1.91090] *$} & & & \\
\hline April & -0.00083 & {$[-1.46729]$} & & & \\
\hline May & -0.00080 & {$[-1.56046]$} & & & \\
\hline June & -0.00090 & {$[-1.61670]$} & & & \\
\hline August & -0.00166 & {$[-2.92447] * * *$} & & & \\
\hline September & -0.00087 & {$[-1.44302]$} & & & \\
\hline October & -0.00128 & {$[-2.02057] * *$} & & & \\
\hline November & -0.00069 & {$[-1.27021]$} & & & \\
\hline December & -0.00054 & {$[-0.95826]$} & & & \\
\hline$D W$ & 1.99061 & & $D W$ & 1.99061 & \\
\hline Levene & $0.02100 * *$ & & Levene & 0.46826 & \\
\hline van der Waerden & 12.88802 & & van der Waerden & $5.67671 * *$ & \\
\hline F-Value & 1.05037 & & F-Value & $5.71929 * *$ & \\
\hline
\end{tabular}

*** Significant at $1 \%$ level;

** Significant at $5 \%$ level;

* Significant at $10 \%$ level;

t-statistics in brackets are the White [1980] adjusted t-statistics

The second test suggests that the average daily return in July is significantly higher than that in the non-July months, based on the significant (at $5 \%$ level) t-statistic, van der Waerden statistic and F-value. Compared with the non-July months as a whole, July has an average excess daily return of 10 basis points. With 244 days in July over the 11-year study period, this will translate into an excess return of $2.3 \%$ per annum over that period, if there were no transaction costs.

In summary, there is no evidence that the monthly effect exists in the broader equity market. In the LPT market, there is no January effect that is evidenced by previous studies on common stocks. However, it appears that July has constantly attracted significantly higher average daily returns compared with the other months as a whole as well as with some of the other months individually. This July effect in the LPT market provides potential for abnormal returns by selling in July.

Pre-holiday effect

Table 8 presents the results of the pre-holiday effect. 
As shown in Table 8, for the entire study period, the insignificance of the tstatistics, F-value and van der Waerden statistic suggests that the pre-holiday effect does not exist in the broader equity market.

Table 8:Pre-holiday effect for LPT and stock market (1 June 1992 - 30 May 2003)

\begin{tabular}{llllr}
\hline \multicolumn{2}{c}{ LPTs } & \multicolumn{2}{c}{ All Ords } \\
& Coefficient & t-Statistics & Coefficient & $t$-Statistics \\
Constant & 0.00015 & 1.27513 & 0.00022 & {$[1.39232]$} \\
Pre-Holiday & 0.00123 & 1.51930 & 0.00033 & {$[0.42209]$} \\
& & & \\
DW & 1.98385 & & 1.92309 & \\
Levene & 1.57235 & & $4.74501 * *$ & \\
van der Waerden & $3.10106 *$ & & 0.12977 & \\
F-Value & 2.30828 & & 0.09701 & \\
\hline
\end{tabular}

*** Significant at $1 \%$ level;

** Significant at $5 \%$ level;

* Significant at $10 \%$ level;

t-statistics in brackets are the White [1980] adjusted t-statistics.

For LPTs, while the t-statistics and F-value are insignificant, suggesting no preholiday effect, the nonparametric test (van der Waerden) is significant suggesting the existence of such an effect. This may be simply because that, in the LPT market, there exist differences in the daily returns between pre-holiday trading days and the other trading days, but for the entire study period, this effect is not strong enough for the $\mathrm{t}$-statistic and F-value to be significant.

To examine whether this is the case, LPTs are further examined and it is found that significant pre-holiday effect does exist in the early days in the 11-year study period, but this effect diminishes over time and dissipates after 31 May 2001. Table 9 presents the results.

As shown in Table 9, the first sub-sample (sub-sample 1) takes the period of 1 June 1992 to 31 May 1994. The sub-sample is then extended by a two-year interval until 31 May 2000, i.e., sub-sample 2 (1 June 1992 to 31 May 1996), sub-sample 3 (1 June 1992 to 29 May 1998) and sub-sample 4 (1 June 1992 to 31 May 2000). The last sub-sample (sub-sample 5) ends up with 31 May 2003, where the pre-holiday effects disappear. 
Table 9: Pre-holiday effect for LPT and stock markets (sub-samples)

\begin{tabular}{|c|c|c|c|c|c|c|}
\hline & \multicolumn{2}{|c|}{$\begin{array}{c}\text { LPTs (Sub-sample 1) } \\
\text { (1 June 1992 - 31 May 1994) }\end{array}$} & \multicolumn{2}{|c|}{$\begin{array}{c}\text { LPTs (Sub-sample 2) } \\
\text { (1 June } 1992 \text { - 31 May 1996) }\end{array}$} & \multicolumn{2}{|c|}{$\begin{array}{c}\text { LPTs (Sub-sample 3) } \\
\text { (1 June } 1992-29 \text { May 1998) }\end{array}$} \\
\hline & Coefficient & $t$-Statistics & Coefficient & $t$-Statistics & Coefficient & t-Statistics \\
\hline Constant & 0.00013 & 0.48274 & -0.00004 & -0.21064 & 0.00017 & 1.10381 \\
\hline Pre-Holiday & 0.00490 & $2.63928 * * *$ & 0.00245 & $2.05670 * *$ & 0.00202 & $1.97352 * *$ \\
\hline$D W$ & 2.00052 & & 2.00919 & & 2.04829 & \\
\hline Levene & 1.01655 & & 0.75941 & & 1.53134 & \\
\hline van der Waerden & $7.30068 * * *$ & & $4.95415 * *$ & & $5.13824 * *$ & \\
\hline \multirow[t]{3}{*}{ F-Value } & $6.96579 * * *$ & & $4.23000 * *$ & & $3.89479 * *$ & \\
\hline & $\begin{array}{r}\text { LPTs (Sul } \\
\text { (1 June } 1992 \text { - }\end{array}$ & $\begin{array}{l}\text { sample 4) } \\
\text { May 2000) }\end{array}$ & $\begin{array}{r}\text { LPTs (Su } \\
\text { (1 June } 1992\end{array}$ & $\begin{array}{l}\text { sample 5) } \\
\text { May 2001) }\end{array}$ & & \\
\hline & Coefficient & $t$-Statistics & Coefficient & $t$-Statistics & & \\
\hline Constant & 0.00010 & 0.69963 & 0.00010 & 0.77789 & & \\
\hline Pre-Holiday & 0.00166 & $1.70364 *$ & 0.00152 & $1.67122 *$ & & \\
\hline$D W$ & 2.00604 & & 1.98536 & & & \\
\hline Levene & 1.99081 & & 0.89082 & & & \\
\hline van der Waerden & $3.75061 *$ & & $3.76616 *$ & & & \\
\hline F-Value & $2.90240 *$ & & $2.79299 *$ & & & \\
\hline
\end{tabular}

*** Significant at $1 \%$ level;

$* *$ Significant at $5 \%$ level;

* Significant at $10 \%$ level;

t-statistics in brackets are the White [1980] adjusted t-statistics.

In Table 9, not only the significance level of the t-statistics, F-values and van der Waerden statistics is declining with the extension of testing period, the magnitude of the coefficient for pre-holiday is also decreasing. This implies that the preholiday effect has been significant in the early days of the study period, but the significance of this effect is declining over time, until disappearing totally, suggesting the move towards higher efficiency.

In summary, for the entire study period, there is no evidence of the pre-holiday effect either in the LPT market or the broader stock market. However, in the LPT market, pre-holiday effect does exist in the early days of the study period. The evidence of a diminishing pre-holiday effect may well suggest a move towards higher levels of efficiency.

Turn-of-the-month effect

Table 10 shows the results for the turn-of-the-month effect.

The results are consistent for LPTs and All Ordinaries. The t-statistics, F-values and the van der Waerden statistics are all significant, suggesting the existence of significant turn-of-the-month effect in both LPTs and the broader equity markets. 
Table 10: Turn-of-the-month effect for LPT market and December effect for stock market (1 June 1992 - 30 May 2003)

*** Significant at $1 \%$ level;

\begin{tabular}{|c|c|c|c|c|}
\hline & \multicolumn{2}{|c|}{ LPTs } & \multicolumn{2}{|c|}{ All Ords } \\
\hline & Coefficient & t-Statistics & Coefficient & $t$-Statistics \\
\hline Constant & 0.00007 & {$[0.55650]$} & 0.00005 & 0.30333 \\
\hline Turn-of-the-Month & 0.00059 & {$[1.82415] *$} & 0.00097 & $2.38512^{* *}$ \\
\hline$D W$ & 1.98478 & & 1.92706 & \\
\hline Levene & $2.94511 *$ & & 0.60032 & \\
\hline van der Waerden & $3.12388 *$ & & $5.42771 * *$ & \\
\hline F-Value & $3.72099 *$ & & $5.68881 * *$ & \\
\hline
\end{tabular}

** Significant at 5\% level;

* Significant at $10 \%$ level;

t-statistics in brackets are the White [1980] adjusted t-statistics.

The average daily excess returns on the turn-of-the-month trading days are 5.9 basis points and 9.7 basis points for LPTs and All Ordinaries respectively, compared with the average daily returns on the other trading days. With 509 days (Table 2) falling into the turn-of-the-month trading days over the 11-year study periods, this implies the potential for obtaining an average excess return of $2.7 \%$ and $4.5 \%$ per annum in LPTs and the broader stock markets respectively, if there were no transaction costs.

\section{PRACTICAL IMPLICATIONS}

The investigations on whether the EMH holds for Australian LPTs and the broader equity markets are important to determining the management styles between active and passive management/investing. Managers who are supportive of active management/investing argue that markets are inefficient and therefore outperformance can result from their skills and expertise in the specific markets. However, if markets are efficient, then buying and selling securities in an attempt to outperform the market will effectively be a game of luck rather than skill.

Financial markets are flooded with intelligent, well-educated and well-paid investment analysts and portfolio managers who are seeking under or over-valued securities to buy or sell in order to achieve out-performance. In theory, the competitions between these investment professionals should eliminate any speculative and arbitrage opportunities, resulting in market efficiency. In an efficient market, active management will become a zero-sum game, because current prices reflect all information and the only way an investor can profit will be purely by luck and at the expense of the loss from another less fortunate active participant. In such a case, the primary role of a portfolio manager, rather than seeking to beat 
the market, should focus on tailoring a portfolio to investors' risk preferences, tax considerations etc.

The presence of calendar anomalies suggests that LPTs and the broader equity markets are inefficient in the semi-strong form, because prices are not only driven by information alone, but also some other factors.

While only the turn-of-the-month effect exists in the broader equity market, there are the day-of-the-week effect, monthly effect and the turn-of-the-month effect evidenced in the LPT market. As illustrated in Section three, the accumulated excess returns that may be realised from these effects are significant. For example, ignoring transaction costs, the potential for profiting from the day-of-the-week effect may be as large as $4.9 \%$ per annum in the LPT market and there is the potential for profiting $4.5 \%$ per annum from the turn-of-the-month effect in the broader equity market. Taking into accounts of transaction costs, which are in the range of 10 to 30 basis points for institutional investors in the Australian markets, the exploitable opportunity from the calendar anomalies are certainly limited. However, if portfolio managers who are planning to make a shift in the portfolio compositions can time the trades to take advantage of these anomalous regularities, they will be able to save a few basis points on each trade. Over time, a few basis points aggregated from a large number of transactions can significantly impact returns.

This study also provides support to the EMH theory, in that competition from rational investors will eliminate arbitrage opportunities and drive markets towards market efficiency or higher levels of efficiency. For example, there exists the preholiday effect in the early days of the study period in the LPT market. However, both the magnitude and the level of significance of this effect in LPT markets are diminishing over time and dissipating eventually. This may well suggest a move towards a higher level of efficiency driven by competition from rational investors, supporting the theory of EMH. Moreover, it appears that the broader equity market is more efficient than the LPT market. For example, for the four calendar anomalies tested in this study, only the turn-of-the-month effect exists in both markets, and the day-of-the-week and monthly effects are evidenced in the LPT market but not the broader equity market. This may simply be because that LPT market has a short history and is less mature than the broader equity market; again, suggesting the move towards higher levels of efficiency over time. All these imply that the potential for profiting from the anomalous regularities would not last forever, and portfolio managers should investigate and take advantages of those opportunities sooner rather than later.

The results from this study provide evidence that LPTs and the broader equity markets are inefficient in the semi-strong form, and support active management/investing. An interesting phenomenon regarding the EMH is that 
market efficiency depends on the belief that markets are not efficient, and is driven by the attempt to outperform the market by market participants who believe the market is inefficient. If every investor believed that a market was efficient (a case for passive management/investing), then the market would not be efficient because no one would analyse securities and it would be unlikely for securities prices to fully reflect all available information. In fact, the weak form efficiency in the Australian LPT and the broader equity markets, as evidenced in Peng (2004a) may simply result from the competitions by active managers and rational investors seeking out performance in the presence of semi-strong form inefficiency such as the calendar anomalies evidenced in this study.

\section{CONCLUSION}

This study inspects the semi-strong form of efficient market hypothesis (EMH). It provides a comprehensive examination of calendar anomalies in the Australian capital markets, particularly the LPT market. In the field of real estate studies, it puts the examination of calendar anomalies into the context of EMH inspection; more specifically, semi-strong form EMH inspection.

The results of this study provide evidence that calendar anomalies exist in the LPT and the broader equity markets. This suggests that the LPTs and broader equity markets are inefficient in the semi-strong form, which provides opportunities for profiting abnormal returns. This paper further quantifies the abnormal returns that could be potentially achieved by active managers who would utilise the findings of the study.

This paper also illustrates how the opportunities to obtain abnormal returns could diminish and dissipate over time, and suggests that portfolio managers should investigate and take advantage of these opportunities sooner rather than later.

Finally, it provides strong reasoning for supporting active management and investing as opposed to passive management and investing.

\section{REFERENCES}

Abraham, A. and Ikenberry, D. (1994), The individual investor and the weekend effect. Journal of Financial Quantitative Analysis, 29:2, 263-277.

Admati, A. and Pfleiderer, P. (1989), Dividend and conquer: a theory of intraday and day-of-the-week mean effects. The Review of Financial Studies, 2:2, 189-223.

Ariel, R. (1987), The monthly effect in stock returns. Journal of Financial Economics, 18, 161-174.

Pacific Rim Property Research Journal, Vol 11, No 1 
Ariel, R. (1990), High stock returns before holidays: existence and evidence on possible causes. The Journal of Finance, 45:5, 1611-1626.

Brown, P., Keim, D., Kleidon, A. and Marsh, T. (1983), Stock return seasonalities and the tax-loss selling hypothesis: analysis of the arguments and Australian evidence. Journal of Financial Economics, 12, 105-127.

Brown, M. and Forsythe, A. (1974), Robust tests for the equality of variances. Journal of the American Statistical Association, 69, 364-67.

Colwell, P. and Park, H. (1990), Seasonality and size effects: the case of real-estaterelated investment. Journal of Real Estate Finance and Economics, 3, 251-259.

Conover, W. (1980), Practical Nonparametric Statistics (Second Edition). John Wiley \& Sons: New York.

Cross, F. (1973), The behaviour of stock prices on Fridays and Mondays. Financial Analysts Journal, November-December, 67-69.

Fama, E. (1970), Efficient capital markets: a review of theory and empirical work. The Journal of Finance, 25, 383-417.

Flannery, M. and Protopapadakis, A. (1988), From t-bills to common stocks: investigating the generality of intra-week return seasonality. The Journal of Finance, 43:2, 431-450.

French, K. (1980), Stock returns and the weekend effect. Journal of Financial Economics, 9, 55-69.

Friday, H. and Higgins, E. (2000), The day of the week effect in real estate investment trusts. Journal of Real Estate Portfolio Management, 6:3, 273-282.

Gibbons, M. and Hess, P. (1981), Day of the week effects and asset returns. Journal of Business, 1981, 54:4, 579-596.

Hansen, L. (1982), Large sample properties of generalized method of moments estimators. Econometrica, 50, 1029-1054.

Harris, L. (1986), A transaction data study of weekly and inter-daily patterns in stock returns. Journal of Financial Economics, 15, 99-117.

Jaffe, J. and Westerfield, R. (1985), The week-end effect in common stock returns: the international evidence. The Journal of Finance, 40:2, 433-454. 
Keim, D. (1985), Dividend yields and stock returns: implications of abnormal January returns. Journal of Financial Economics, 14, 473-490.

Keim, D. (1983), Size-related anomalies and stock return seasonality: further empirical evidence. Journal of Financial Economics, 12, 13-32.

Keim, D. and Stambaugh, R. (1984), A further investigation of the weekend effect in stock returns. The Journal of Finance, 39:3, 819-835.

Liu, C. and Mei, J. (1992), The predictability of returns on equity REITs and their co-movement with other assets. Journal of Real Estate Finance and Economics, 5:4, 401-418.

Ogden, J. (1990), Turn-of-month evaluations of liquid profits and stock returns: a common explanation for the monthly and January effects. The Journal of Finance, $45: 4,1259-1272$.

Peng, V. (2004a), Price predictability and capital market efficiency: listed property trust investment strategies. Pacific Rim Property Research Journal, 10:4, 451-466.

Peng, V. (2004b). Selectivity, timing and the performance of listed property trusts: implications for investment strategies. Pacific Rim Property Research Journal, $10: 2,235-255$.

Redman, A., Manakyan, H. and Liano, K. (1997), Real estate investment trusts and calendar anomalies. Journal of Real Estate Research, 14: 1, 19-28.

Roll, R. (1983), The turn of the year effect and the return premium of small firms. Journal of Portfolio Management, 9, 18-28.

Rozeff, M. and Kinney, W. (1976). Capital market seasonality: the case of stock returns. Journal of Financial Economics, 3, 379-402.

Wang, K., Li, Y. and Erickon, J. (1997), A new look at the Monday effect. The Journal of Finance, 52:5, 2171-2186.

White, H. (1980), A heteroscadasticity-consistent covariance matrix estimator and a direct test for heteroscadasticity. Econometrica, 48, 817-838. 